\title{
COACHING, MENTORING AND CONSULTATION: THE SAME BUT DIFFERENT ACTIVITIES IN SUPERVISION OF SOCIAL WORKERS IN SOUTH AFRICA?
}

\section{Lambert Engelbrecht}

\section{INTRODUCTION}

The historical roots of the supervision of social workers in South Africa can be traced back to the year when the country first became a Republic (Pieterse, 1961). An official definition of social work supervision was provided ten years later (Vaktaalkomitee vir Maatskaplike Werk, 1971) and it was only another decade later that supervision was presented as a postgraduate course at some universities (Hoffmann, 1987). Academics such as Botha (1985), De Bruyn (1985), Hoffmann (1987) and Pelser (1985) played a significant role in conceptualising and theorising supervision as an important and essential activity in social work. In due course the transition to a new political dispensation and welfare system in the country in the 1990s led to, inter alia, a "brain drain" of supervision expertise (Engelbrecht, 2006), which was counteracted by the Department of Social Development in the first decade of the new millennium by means of a recruitment and retention strategy, and by declaring social work a scarce skill (Department of Social Development, 2006).

The Recruitment and Retention Strategy (Department of Social Development, 2006) introduced and referred to contemporary, albeit tacit, concepts (Collins-Camargo \& Kelly, 2006) such as mentoring in the same sense as supervision of social workers. These references were probably a neoliberal response as suggested by Kobeleva and Strongman (2010) to the Public Service Mentorship Programme of the Department of Public Service and Administration (2006:5), which specifically stated that "South African government departments are developing and implementing mentorship programmes as part of a broader plan to improve capacity in the public sector". In turn, in a move also intended to improve the capacity of the social work fraternity, the South African Council for Social Service Professions (SACSSP) and the National Department of Social Development (DSD) embarked on a process to construct a supervision framework for the social work profession (DSD \& SACSSP, 2012). Noteworthy in this supervision framework are the interchangeable references to mentoring and coaching of social workers, and consultation as an activity of supervision.

This interchangeable use of coaching, mentoring, consultation and supervision may thus rightfully be regarded as a neoliberal tendency (Rosén, 2011), with its origin in the market and corporate business. Gallacher (1997) conceded that these concepts are intrinsically not the same, but share overlapping foundations, processes, purposes, elements and competencies, resulting in an uncritical use of the concepts (Rosén, 2011). Although Tsui (2005:77) referred, in a social work context, to these concepts as activities in supervision, this reference does not ultimately clarify the confusion or the "borrowed clothes" (Hawkins \& Schwenk, 2006:3) regarding the use and application of the concepts concerned. Bluckert (2008) refers, for instance, to a coach/mentor who must maintain a relationship with a suitably qualified supervisor and coaches who expect to have regular consultative support. In the same vein, Perrault and Coleman (2005) regard coaching and mentoring as a requisite and useful skill for social work supervisors. Hafford-Letchfield, Leonard, Begum and Chick $(2008: 119,164)$ even refer within an English context to "coach mentoring", but also to "group/team supervision" as an example of an innovative approach to supervision and "consulting" services to carers. These 
examples clearly show the differences in the contextual use of the terms, which have definite implications for interpretation and utilisation.

A direct implication of these differences and similarities for utilisation of coaching, mentoring, consultation and supervision, as specifically emphasised by Gallacher (1997), is the challenges of role confusion they present, especially when dual roles occur. Turner (2000) refers to these challenges as an important debate in social work, with detrimental implications for organisations, as a result of the potential conflict in the misuse and misapplication of the concepts. Gallacher (1997) thus rightfully attests that the concepts concerned must be carefully examined in order to illuminate the similarities and differences, as these concepts, when operationalised as activities, form the backbone of social work's aspiration to render the best possible services to service users (Kadushin \& Harkness, 2002). However, although authors such as Taibbi (1983) outlined the rationale for the use of concepts such as mentoring and supervision decades ago, Collins-Camargo and Kelly (2006) observed that this is rarely discussed in international academic literature. Bluckert (2008) anticipates that this topic will nevertheless receive much greater global attention in the years to come as new supervision models, guidelines and frameworks emerge - all as a result of activities such as coaching, mentoring and consultation, whose neoliberal roots are embedded in economic and ideologically driven agendas of international and local structural forces (Kobeleva \& Strongman, 2010).

To this end it is contended in Coaches and Mentors of South Africa (COMENSA, 2010) that in recent years the use of coaching, mentoring and consultation has also gained prominence in South Africa in all spheres of society. The traces of this propensity are likewise evident within the context of social work supervision (Department of Social Development, 2006; DSD \& SACSSP, 2012). Since the prominence of these concepts is well articulated in public social work-related documents, but with no significant, critical and scholarly theoretical substantiation, this article seeks to address the question on the similarities and/or differences between coaching, mentoring and consultation as supervision activities. The core determinants of each concept will be examined with a view to presenting a South African context-specific approach to social work supervision activities. This contribution hopes to stimulate critical debate on the use of theoretical concepts concerning supervision of social workers, specifically in public and organisational policy-related documents, which potentially have drastic implications when operationalised in practice.

\section{SUPERVISION OF SOCIAL WORKERS}

The implicit meaning of supervision in a general context is to oversee work and workers (Kadushin, 1976). Through the contributions of Mary Richmond (1899) and Brackett (1904) in charitable social agencies in Europe and North America, the supervision of social workers became topical and distinctive in social work. However, to define supervision of social workers per se is still a daunting task, as it appears that definitions of supervision are exceptionally context specific, changing in various ways at different times, and are determined by normative, pragmatic and empirical approaches (Barker, 1995; Tsui, 2005). For example, definitions of "clinical supervision" (Goldhammer, Anderson \& Krajewski, 1993:4) within the North American context specifically focus on supervision of workers employed in human service organisations (Lewis, Packard \& Lewis, 2012) as well as in a range of interdisciplinary and para-professions (Fifth International Interdisciplinary Conference on Clinical Supervision, 2009). Other definitions conversely concern supervision practices as not necessarily organisation-based (Bogo \& McKnight, 2005; Tromski-Klingshirn, 2006). First-hand 
observations of supervisees' professional events are also perceived as essential, but some definitions advocate that supervision may benefit from supervisees' articulations about their professional events (Goldhammer et al., 1993). Within the South African social development paradigm (RSA, 1997) and according to the country's integrated service delivery model towards rendering improved social services (RSA, 2006), social work methods may range from micro to macro practices, which will typically make supervisors' direct observations of supervisees' practices impossible and which may also be regarded as antithetical to clinical practices and supervision.

To this end Kadushin's (1976) definition of supervision becomes helpful in defining supervision of social workers in South Africa, as he drew on John Dawson's (1926) functions of supervision in terms of administration, education and support, which were embraced by prominent South African scholars on the topic (Botha, 1985). Consequently Kadushin's postulations on supervision functions also contributed significantly to the 1995 definition of social work supervision in the South African New Dictionary of Social Work (Terminology Committee for Social Work, 1995:64) as a "process whereby the supervisor performs educational, supportive and administrative functions in order to promote efficient and professional rendering of services".

The 1995 supervision definition of the Terminology Committee for Social Work should, however, be seen against the backdrop of the country's Social Work Act (RSA, 1978). As social work in South Africa is a profession regulated by the South African Council for Social Service Professions (SACSSP), the definition of supervision is ultimately subject to the Ethical Code of the SACSSP (2007). Three clauses, among others, of the Ethical Code specifically guide the definition of supervision practices in South Africa, namely: "Social workers should take reasonable steps to ensure that adequate agency or organisational resources are available to provide appropriate staff supervision" (5.4.5 [c] ); "The supervisor could be held liable in an instance where a complaint of alleged unprofessional conduct is lodged against the supervisee/social worker" (5.4.1 [e]); and "A social worker should be supervised on social work matters by a supervisor who is registered as a social worker" (5.4.1 [f]).

As a recent development in the South African social work fraternity, a definition of social work supervision has been compiled as part of a supervision framework for the social work profession (DSD \& SACSSP, 2012:18). This supervision framework evidently reflects applicable clauses of the Ethical Code (SACSSP, 2007), elements of Kadushin's (1976) definition on supervision and those of the Terminology Committee for Social Work (1995) as follows: "Supervision is a formal arrangement where supervisees review and reflect on their work. It is related to ongoing learning and performance. Social work supervision is an interactional process within the context of a positive anti-discriminatory relationship, based on distinct theories, models and perspectives on supervision whereby a supervisor with the required experience and qualification, and to whom authority is delegated, supervises a social worker, student social worker, social auxiliary worker and learner auxiliary worker by performing educational, supportive and administrative functions in order to promote efficient and professional rendering of social work services." Significantly, this definition clearly perceives supervision as formalised, interminable and not exclusively based on supervisors' tacit knowledge. The operationalising of supervision is rather theoretically founded within a specific body of knowledge. Requirements are also set in terms of the competencies of supervisors and their managerial hierarchical positions. Kadushin's (1976) typical functions of supervision are apparent as well as the distinctive primary goal of supervision. It is also evident 
that the definition refers to different levels and stages of social workers' professional development, which is unique and not distinguishable in other conventional international or previous local definitions.

This reference to the various levels and stages of a social worker's professional development may hold the answer to the question on differences/similarities of activities in supervision as it coincides with the following suggestion of Gallacher (1997:196), which fundamentally directs and underpins the examining of coaching, mentoring and consultation as similar/different activities in supervision: "the paradigm in supervision is shifting to one that empowers practitioners, integrates the functions and activities of supervision, and recognizes the diversity of practitioners (i.e. their unique levels, needs, interest, and abilities)". This shift in the supervision paradigm will be clarified in the following sections. The interminable and statutory nature of social work supervision in South Africa (SACSSP, 2007) is, however, the backdrop of the supervision activities to be discussed.

\section{COACHING}

"Coaching supervision" (Hawkins \& Schwenk, 2006:3) is a relatively new concept. Perrault and Coleman (2005) promote the concept as a disposition and assert that it should be included in future conceptualisations of social work supervision practices. In the business sector COMENSA (2010) defines coaching as a professional, collaborative and outcomes-driven method of learning that seeks to develop an individual and raise self-awareness so that he or she might achieve specific goals and perform at a more effective level.

The conceptualisation suggested by COMENSA (2010) evidently concurs with Perrault and Coleman's (2005) exposition of the core elements of coaching within a social work context, which include the provision of instruction, guidance of practice skills and feedback. These authors conclude that coaching fits well within an educational supervision paradigm and that this activity especially offers the opportunity for social work field instructors to fulfil supervision functions in practice education. Perrault and Coleman (2005) furthermore observe that coaching follows the same processes as those being used in supervision of social workers, but in addition it parallels Bogo and Vayda's (1998) Integrated Theory and Practice (ITP) Loop process. This process includes four components of typical practice education in terms of retrieval of experiences, reflection, linkage with formal knowledge and evaluation of the student's professional responses.

From these suggestions it may be deduced that coaching is more structured and systematic than mentoring. Gallacher (1997) similarly attests that coaching is narrower in scope than mentoring as its primary purpose is the refinement of specific practices. In comparison with mentoring, coaching thus generally has a set duration, is more directive in nature, is more short term, and is more focused on specific development areas (Connor \& Pokora, 2007). These determinants are mirrored within the South African higher learning context, where social work students have to complete fixed practice education programmes directed by specific aims, within predetermined academic timeframes, and which are based on a set of exit-level outcomes (Lombard, Grobbelaar \& Pruis, 2003). In summary, within this context coaching may be regarded as the equivalent of and a synonym for practice education (Perrault \& Coleman, 2005).

Connor and Pokora (2007) view coaching and mentoring as complementary activities as both are learning relationships which help supervisees to take charge of their own development. This implies that coaching and mentoring may be parallel activities on a continuum of supervision 
practices. Because of the intrinsic instructional nature of coaching, this activity appears to be more prominent in the practice education of student social workers. However, both activities may focus on student social workers' transition to becoming newly qualified social workers and beyond. Mentoring activities, which are less instructional than coaching, will ultimately increase gradually proportionate to the experience of the social worker. The following analyses of mentoring will shed more light on this explanation.

\section{MENTORING}

Literature on mentoring in social service organisations has been criticised for a lack of conceptual clarity (Kelly, 2001), despite the fact that Taibbi (1983) several years ago outlined a rationale for social work supervisors mentoring their staff. Collins-Camargo and Kelly (2006:129) confirm that mentoring in supervision is still under-researched, although it would do the social work profession well to consider this topic, especially because supervisors in other helping professions such as nursing and teaching have been encouraged to mentor staff. Therefore the latter authors are convinced that mentoring within the context of social work supervision may have unique elements worthy of further study.

Kelly (2001) offers a critical dissection of unique elements in mentoring which elucidates the wide range of mentor definitions within different contexts. In probably the most influential definition on mentorship in social work, based on an extensive survey of 430 social workers' perceptions, Collins (1994:414) defines mentoring as "an interpersonal helping relationship between two individuals who are at different stages in their professional development. The mentor - the more professionally advanced of the two - facilitates the development and advancement of the protégé - the junior professional - by serving as a source of social support beyond what is required solely on the basis of their formal role relationship". Typical of this definition - and as aspect which is also referred to in definitions of mentoring by Barnett, Youngstrom and Smook (2001), Collins-Camargo and Kelly (2006) and Gallacher (1997) - is the emphasis on the distinct relationship between the mentor and protégé beyond their formal roles. This perspective on mentoring as an additional activity in social work supervision is also echoed by Tsui (2005), but according to Barnett et al. (2001), however, it is not necessarily designated and is merely an evolutionary process, although it may be one of the most important influences in shaping a supervisee's working career. These influences are specifically relevant, especially as the supervisor acts as role model for the protégé when the worker is newly qualified and thus in the first year of being a social worker.

The extension of the supervisory relationship to include mentorship qualities is also supported by Cloete's (2012) research on the features and use of mentoring as activity in supervision of newly qualified social workers in South Africa. It is concluded in this research that mentoring follows intrinsically the same processes, techniques and methods as supervision. These conclusions agree with other opinions expressed in South Africa, such as those by the Public Service Mentorship Programme of the Department of Public Service and Administration (2006), suggesting that mentoring does not replace, but supplements, the role of an individual's immediate supervisor in order to accelerate and improve induction/orientation in the early stages of employment. The focus is thus fundamentally on comprehensive on-the-job learning by the supervisee and the transfer of skills by the supervisor, as the supervisor is demonstrating and facilitates the required competencies.

These conceptualisations of mentoring mirror Taibbi's (1983:238) arguments, as the author observed that mentoring resonates with supervision functions (support, education and 
administration), but "include[s] functions beyond the performing of training and accountability tasks, and it calls for an investment in a learning relationship that more fully addresses the student's or beginning worker's developmental needs". This development approach towards supervision, as stated by Kadushin and Harkness (2002), accords with a variation of additional supervision activities, where the supervisees can observe, consult and copy their mentors (supervisors) as skilled performers. In this context Gallacher (1997) clearly affirms the distinction between supervision and mentoring, specifically with references to supervision's broader scope, administration function and consequently performance evaluation. Hence, mentoring is an informal activity within supervision, focuses on role modelling by the supervisor, who is imitated by the beginner social worker. Measurements of effectiveness and efficiency are therefore usually not objectives of mentoring in supervision of social workers.

To this end, Taibbi (1983:105), as a primary author on mentoring in supervision, states that, "if social work does not clearly address the developmental needs of novice workers and omits opportunities for mentorship from the professions' training models because of a too-narrow focus on measured effectiveness and efficiency and on structured, time-limited contracts, it may well be limiting the potential value of supervision, distorting the professionalization of the novice, and constricting the life blood of the profession and of its individual members." This view is attested to by Cloete's (2012) research, as she affirms the need for mentoring in supervision with an eye to the retention of newly qualified social workers, particularly in the light of social work being declared a scare skill in South Africa (Department of Social Development, 2006). This argument prompts further examination of supervision of experienced social workers, which will be expounded in the next section.

\section{CONSULTATION}

Botha (2002:282-327), as one of the primary authors on supervision in South Africa, addressed "social work consultation" in probably one of the most comprehensive texts on supervision in South Africa, it being an updated version of her contributions to the literature on supervision since 1971. She based her views on consultation in social work largely on texts by North American authors such as Kadushin (1977), Rapoport (1977), Austin (1981), Middleman and Rhodes (1985:16) and Steinberg (1989). Botha's (2002:282-283) premises on supervision rely unambiguously on the following commentary by Kadushin (1977:x): "Supervision of social workers should be terminated as early as possible and the relationship between supervisorsupervisee converted into a relationship of consultant-consultee." Botha (2002:12-13) furthermore defines consultation in the following words of Middleman and Rhodes (1985:16):"CConsultation assumes a voluntary meeting between professional peers, initiated by the consultee who seeks advice or reaction from a selected consultant, presumably because the consultant has expertise in the area of concern ... There is a take-it-or-leave-it mentality, depending on the consultee's determination of the worth of the consultation. These differences between consultation and supervision are mainly structural ... we tend to see the major distinctions between supervisor and consultant in structural, role-related, line-versus-staff statuses." Botha (2002) concludes, inter alia, that consultation always follows after an initial period of intense supervision; it is executed according to a process comparable to those of the supervision process; it is voluntary and always advisory in nature; it takes place at the request of the social worker, although it should still be contracted; and it encompasses professional educational and developmental components. Along these lines the main thrust of arguments is that the professional development of the experienced social worker is either embedded in supervision or in consultation. 
These arguments by Botha (2002) influenced perceptions on consultation in social work for many years in South Africa and led to postgraduate theses, such as that of Pretorius (1991). Although these contributions added considerable value to the body of literature on social work, they may be placed within a specific context and time perspective in the global and local development of the social work profession. For instance, although Kadushin introduced his seminal work on consultation in social work in 1977, he produced no consecutive works on the topic and his later publications on supervision (Kadushin, 1985, 1992; Kadushin \& Harkness, 2002) did not refer to consultation at all (not even in the indexes). The Clinical Supervisor, a journal devoted exclusively to supervision, but inclusive of various professions, has published only four article contributions on consultation since 1983 and all these articles refer to consultation within a supervision context (Cramer \& Rosenfield, 2004; Kaslow, 1986; Powell, 1996; Veeder, 1990). In addition, contemporary models of supervision (Nye, 2007) acknowledge the need for social workers' on-going dependence on supervision across their professional careers, implying that supervision is interminable and that dependence on a supervisor should not be regarded as stagnation, but may be part of a developmental learning approach towards supervision.

However, Botha (2002:287) concurs, in what may appear as a paradox in the light of her previously mentioned exposition of consultation, that "the manager/supervisor/consultant who practises consultation in the organisation, remains finally responsible for the administrative processes and control". This correlates with the South African Ethical Code of Social Work, which refers in several clauses to supervision and consultation in the same sense, but unequivocally states that it is the supervisor who could be held liable for unprofessional conduct lodged against a social worker (SACSSP, 2007:5.4.1[e]). These premises are also reflected in the Supervision Framework for the Social Work Profession in South Africa (DSD \& SACSSP, 2012), by defining consultation as an activity of supervision, determined by the supervision contract and performance appraisal after the goals and outcomes of supervision in the initial contract have been achieved. In this way, consultation of the experienced social worker is depicted as part of an overarching supervision process.

\section{CONCLUSION}

An examination of the similarities and/or differences between coaching, mentoring and consultation primarily holds that they are all activities of supervision, as supervision is the baseline context supplemented by these activities. Attempts to isolate and conceptualise these activities outside the context of social work supervision would merely create confusion. This is evident in research (Engelbrecht, 2010) suggesting that advocating an "either-supervision-orconsultation-approach" in South Africa constitutes a fallacy, as this perception of consultation of experienced social workers simply becomes a misnomer for inadequate supervision, disguised as giving the social worker consultee status - but without any contractual, evidence or competency basis. Hence, although it is particularly apparent that the supervision activities concerned all possess similarities in terms of processes, techniques and methods, the main intrinsic differences in features, scope and utilisation lie in three distinct professional development stages of the social worker, which are those of a student, newly qualified and experienced social worker. These identified stages reflect Kadushin's (1976) initial developmental approach to supervision.

According to Kadushin and Harkness (2002:212), "a developmental approach to supervision presupposes that there is growth in the supervisee and that each stage of such growth requires modification in the supervisor's approach to the supervisee. The modifications are required in 
response to changing needs of supervisees at different levels of the growth process". The figure below illustrates this approach graphically within the context of coaching, mentoring and consultation as supervision activities.

\section{SUPERVISION OF SOCIAL WORKERS}

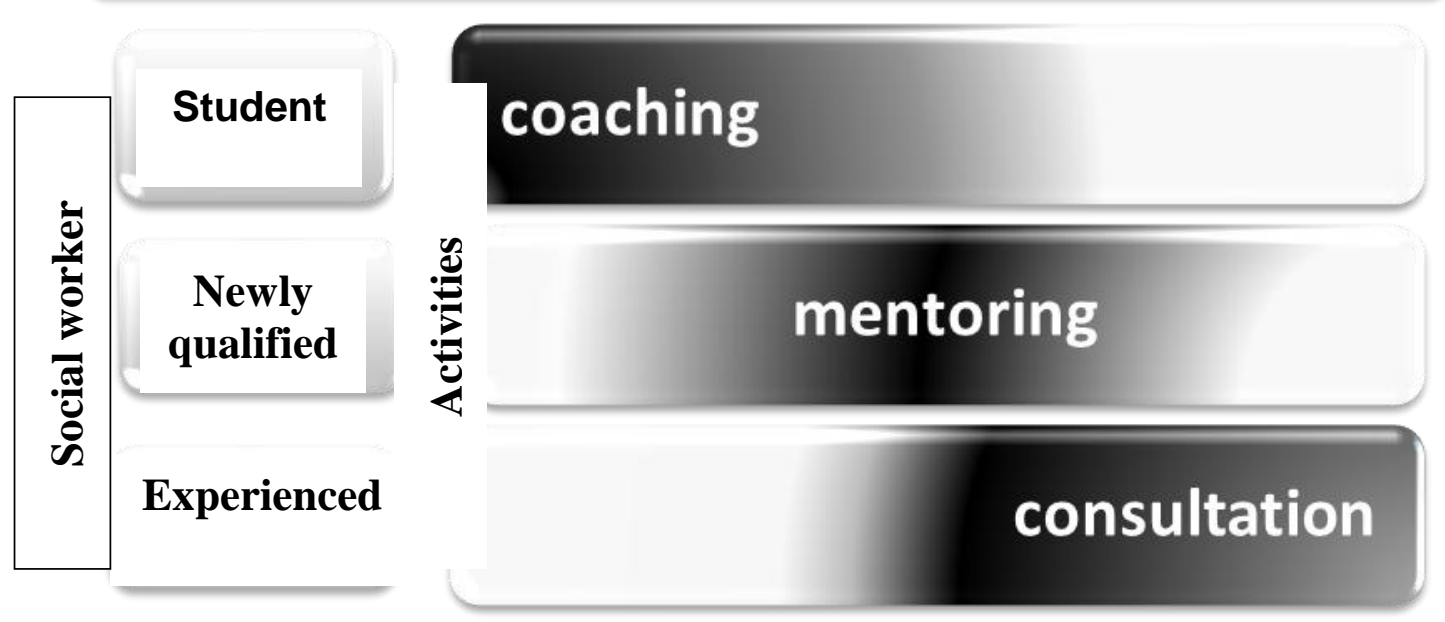

\section{A developmental approach to social work supervision activities}

Drawing on the postulation of a developmental supervision approach by Kadushin and Harkness (2002:212-216), coaching may be interpreted as being more directed to the student social worker, with the primary focus on activities characterised by high levels of instruction, structure and support. Although the development of the student/supervisee may not be absolutely linear, mentoring activities tend to fit the profile of a newly qualified social worker who progressively needs less didactic instruction, but who learns optimally through identification, internalisation and especially imitation. The supervisor eventually becomes less reactive as the supervisee is enabled to integrate practice and theory, and when there is evidence of a growing consolidation of professional identity. Professional development over time means that more experienced social workers require consultations merely on specific issues, as they exhibit increasing individualisation and separateness from the supervisor, and fewer needs for supervisor-imposed structures, support and supervision in general.

Be that as it may, a developmental approach implies that supervision of a social worker is never terminated; and all activities in supervision entail almost similar processes, methods and techniques with slight variations in nuances that are adapted according to the supervisee's different professional developmental stages. The fact is: all these activities are part of an overarching supervision process. Indeed, within the South African context, the answer to the question on the similarities and/or differences between coaching, mentoring and consultation as supervision activities is implied in the words of Kadushin and Harkness (2002:215-216): "Hence, like the good social worker, the good supervisor has to be sensitive to how his or her interventions are being received and modify the approach to optimize the learning situation for the supervisee." The answer to the question raised in this article is thus underpinned by the supervisor's approach to supervision and his/her ability to modify activities to best fit the contexts. 


\section{BIBLIOGRAPHY}

AUSTIN, M.J. 1981. Supervisory management in the human services. Englewood Cliffs, NJ: Prentice-Hall, Inc.

BARKER, R.L. 1995. Social work dictionary ( $3^{\text {rd }}$ ed). Washington, DC: NASW Press.

BARNETT, J.E., YOUNGSTROM, J.K. \& SMOOK, R.G. 2001. Clinical supervision, teaching, and mentoring: Personal perspectives and guiding principles. The Clinical Supervisor, 20(2):217-230.

BLUCKERT, B. 2008. Coaching supervision. [Online] Available: http://www.pbcoaching.com [Accessed: 10/02/2012].

BOGO, M. \& McKNIGHT, K. 2005. Clinical supervision in social work: a review of the research literature. The Clinical Supervisor, 24(1/2):49-67.

BOGO, M. \& VAYDA, E. 1998. The practice of field instruction in social work: theory and process $\left(2^{\text {nd }} \mathrm{ed}\right)$. Toronto: University of Toronto Press.

BOTHA, N.J. 1985. Onderrigmodel vir doeltreffende supervisie. Social Work/Maatskaplike Werk, 21(4):239-248.

BOTHA, N.J. 2002. Supervision and consultation in social work. Bloemfontein: Drufoma.

BRACKETT, J.R. 1904. Supervision and education in charity. New York: Macmillan.

CLOETE, V. 2012. The features and use of mentoring as an activity in supervision of newly qualified social workers. Stellenbosch: University of Stellenbosch. (MA thesis)

COLLINS, P.M. 1994. Does mentorship among social workers make a difference? An empirical investigation of career outcomes. Social Work, 39(4):413-419.

COLLINS-CAMARGO, C. \& KELLY, M. 2006. Supervisor as informal mentor: promoting professional development in public child welfare. The Clinical Supervisor, 25(1/2):127-146.

COMENSA (Coaches and Mentors of South Africa). 2010. Coach/Mentor Supervision Policy. [Online] Available: http://www.comensa.co.za/Portals/0/downloads/Coach\%20-\%20 Mentor\% 20Supervision\%20Policy\%20-\%20April\%202010.pdf [Accessed: 10/02/2012].

CONNOR, M. \& POKORA, J. 2007. Coaching \& mentoring at work. Developing effective practice. Berkshire: Open University Press.

CRAMER, K. \& ROSENFIELD, S. 2004. Supervision of consultation. The Clinical Supervisor, 22(1):111-124.

DAWSON, J.B. 1926. The casework supervisor in a family agency. Family, 6:293-295.

DE BRUYN, M. 1985. Opleiding en toerusting van supervisors. Paper presented at a symposium on supervision. Pretoria: University of Pretoria, 22-23 August.

DEPARTMENT OF PUBLIC SERVICE AND ADMINISTRATION. 2006. The public service mentorship programme. Step by step guide. Pretoria: Department of Public Service and Administration.

DEPARTMENT OF SOCIAL DEVELOPMENT. 2006. Draft recruitment and retention strategy for social workers. Pretoria: Department of Social Development. 
DSD \& SACSSP (DEPARTMENT OF SOCIAL DEVELOPMENT \& SOUTH AFRICAN COUNCIL FOR SOCIAL SERVICE PROFESSIONS). 2012. Supervision framework for the social work profession. Unpublished document.

ENGELBRECHT, L.K. 2006. Plumbing the brain drain of South African social workers migrating to the UK: challenges for social service providers. Social Work/Maatskaplike Werk, 42(2):101-121.

ENGELBRECHT, L.K. 2010. Yesterday, today and tomorrow: is social work supervision in South Africa keeping up? Social Work/Maatskaplike Werk, 46(3):324-342.

FIFTH INTERNATIONAL INTERDISCIPLINARY CONFERENCE ON CLINICAL SUPERVISION. 2009. The Clinical Supervisor, 28(1):109-111.

GALLACHER, K. 1997. Supervision, mentoring, and coaching. Methods for supporting personnel development. In: WINTON, R.J., McCOLLUM, J.A. \& CATLETT, C. (eds). Performing personnel preparation in early intervention. Issues, models and practical strategies. London: Paul H Brooks Publishing Co.

GOLDHAMMER, R., ANDERSON, R.H. \& KRAJEWSKI, R.J. 1993. Clinical Supervision. Special methods for the supervision of teachers $\left(3^{\text {rd }}\right.$ ed). Fort Worth: Harcourt Brace Jovanovich.

HAFFORD-LETCHFIELD, T., LEONARD, K., BEGUM, N. \& CHICK, N.F. 2008. Leadership and management in social care. London: Sage Publications.

HAWKINS, P. \& SCHWENK, G. 2006. Coaching supervision. London: Chartered Institute of Personnel and Development.

HOFFMANN, W. 1987. Social work supervision. In: McKENDRICK, B.W. (ed). Introduction to social work in South Africa. Pinetown: Owen Burgess Publishers: 206-248.

KADUSHIN, A. 1976. Supervision in social work. New York: Columbia University Press.

KADUSHIN, A. 1977. Consultation in social work. New York: Columbia University Press.

KADUSHIN, A. 1985. Supervision in social work $\left(2^{\text {nd }}\right.$ ed). New York: Columbia University Press.

KADUSHIN, A. 1992. Supervision in social work $\left(3^{\text {rd }}\right.$ ed $)$. New York: Columbia University Press.

KADUSHIN, A. \& HARKNESS, D. 2002. Supervision in social work $\left(4^{\text {th }} \mathrm{ed}\right)$. New York: Columbia University Press.

KASLOW, F.W. 1986. Supervision, consultation and staff training - creative teaching/learning processes in the Mental Health Profession. The Clinical Supervisor, 4(1/2):1-16.

KELLY, M.J. 2001. Management mentoring in a social service organization. Administration in Social Work, 25(1):17-33.

KOBELEVA, P. \& STRONGMAN, L. 2010. Mentoring: the socialisation of learning. Lower Hutt, New Zealand: The Open Polytechnic of New Zealand.

LEWIS, J.A., PACKARD, T. \& LEWIS, M.D. 2012. Management of human service programs $\left(5^{\text {th }}\right.$ ed). London: Brooks/Cole CENGAGE Learning. 
LOMBARD, A., GROBBELAAR, M. \& PRUIS, S. 2003. Standards for social work qualifications in South Africa. Social Work/Maatskaplike Werk, 39(1):1-17.

MIDDLEMAN, R.R. \& RHODES, G.B. 1985. Competent supervision. Making imaginative judgements. Englewood Cliffs: NJ: Prentice-Hall.

NYE, C. 2007. Dependence and independence in clinical supervision: an application of Vygotsky's developmental learning theory. The Clinical Supervisor, 26(1/2):81-98.

PERRAULT, E.L.J. \& COLEMAN, H.D.J. 2005. Coaching within social work field education. The Clinical Supervisor, 23(2):47-64.

PELSER, M.F. 1985. Die wetenskaplik professionele regverdiging van supervisie vir maatskaplike werk. Paper delivered at a supervision symposium, Pretoria: University of Pretoria, 22-23 August.

PIETERSE, J.E. 1961. Praktykleiding in groepwerk. Mens en Gemeenskap, 11(3/4):155162.

POWELL, D.A. 1996. Peer Consultation Model for Clinical Supervision. The Clinical Supervisor, 14(2):163-169.

PRETORIUS, E. 1991. Konsultasie in maatskaplike werk. Stellenbosch: Stellenbosch University. (Unpublished DPhil Dissertation)

RAPOPORT, L. 1977. Consultation in social work. In: MORRIS, R. Encyclopaedia of social work, $\mathbf{1 7}^{\text {th }}$ issue, Vol. 1. New York: National Association of Social Workers.

RICHMOND, M.E. 1899. Friendly visiting among the poor: a handbook for charity workers. New York: MacMillan.

ROSÉN, F.F. 2011. No words will deliver anything: coaching and mentoring as neoliberal governance strategy in the Afghan state administration. Journal of Intervention and Statebuilding, 5(2):151-173.

RSA (REPUBLIC OF SOUTH AFRICA). 1978. Act on Social and Associated Workers, Act 110 of 1978. Pretoria: Government Printers.

RSA (REPUBLIC OF SOUTH AFRICA). 1997. Ministry of Welfare and Population Development. White Paper for Social Welfare. Notice 1108 of 1997, Government Gazette, Vol. 386, No. 18166 of 8 August. Pretoria: Government Printers.

RSA (REPUBLIC OF SOUTH AFRICA). 2006. Department of Social Development. Integrated service delivery model towards improved social services. Pretoria: Government Printers.

SACSSP (SOUTH AFRICAN COUNCIL FOR SOCIAL SERVICE PROFESSIONS). 2007. Policy guidelines for course of conduct, code of ethics and the rules for social workers. [Online] Available: http://www.sacssp.co.za/UserFiles/File/ SACSSP\%20Code\%20Ethics.pdf [Accessed: 02/06/2009].

STEINBERG, D. 1989. Interprofessional consultation. Oxford: Blackwell Scientific Publishers.

TAIBBI, R. 1983. Supervisors as mentors. Social Work, 28(3):237-238.

TERMINOLOGY COMMITTEE FOR SOCIAL WORK. 1995. New dictionary of social work. Cape Town: CTP Book Printers. 
TSUI, M. 2005. Social work supervision. Contexts and concepts. London: Sage Publications. TROMSKI-KLINGSHIRN, D. 2006. Should the clinical supervisor be the administrative supervisor? The ethics versus the reality. The Clinical Supervisor, 25(1/2):53-63.

TURNER, B. 2000. Supervision and mentoring in child and family social work: the role of the first-line manager in the implementation of the post-qualifying framework. Social Work Education: The International Journal, 19(3):231-240.

VEEDER, N.W. 1990. Autonomy, accountability, and professionalism: the case against close supervision in social work. The Clinical Supervisor, 8(2):33-47.

VAKTAALKOMITEE VIR MAATSKAPLIKE WERK. 1971. Verklarende Afrikaanse Woordeboek vir Maatskaplike Werk. Departement Volkswelsyn en Pensioene. Pretoria: Government Printer.

Dr Lambert Engelbrecht, Department of Social Work, University of Stellenbosch, Stellenbosch, South Africa. 